\title{
TEACHING SPEAKING TO SENIOR HIGH SCHOOL THROUGH MOVIE DISCUSSION
}

\author{
Lutfiansyah \\ Program of English Education, Faculty of Language and Art, University of Indraprasta PGRI \\ Jalan Nangka No. 58C Tanjung Barat, Jagakarsa, Jakarta Selatan 12530 \\ lutfiharun@yahoo.com
}

\begin{abstract}
The use of film as learning media can support teachers and students in learning speaking English process. Thus, it can develop the speaking skill, language content, and vocabulary mastery of the students. This can be used by the teachers as a media resource to help the students improve their speaking skill. Film is a learning media for learners to access deeper about the introductory of new words, phrase, or even simple sentences. It also assists students to learn more about English expressions. It can be concluded that in order to help the students to practice their speaking skill, the teacher should pay more attention to material, media and activities in the class. The teacher is expected to be a good teacher in facilitating the learning process.
\end{abstract}

Key words: teaching speaking, speaking skill, movie

\begin{abstract}
ABSTRAK
Penggunaan film sebagai media pembelajaran dapat mendukung guru dan siswa dalam proses pembelajaran berbicara bahasa Inggris. Penggunaan media film akan mengembangkan keterampilan berbicara bahasa Inggris siswa, konten bahasa, dan kosakata. Media film dapat digunakan oleh para guru di dalam kelas untuk membantu mengembangkan keterampilan berbicara bahasa Inggris siswa dan juga dapat dijadikan sebagai sumber belajar berbicara. Media film adalah media pembelajaran yang langsung dapat dinikmati siswa dalam pengenalan atau pengucapan kata, frasa, bahkan kalimat-kalimat sederhana. Film dapat membantu siswa dalam mempelajari lebih banyak ekspresi kalimat berbahasa Inggris. Dengan demikian, dapat disimpulkan bahwa untuk membantu siswa dalam melatih keterampilan berbicara mereka, guru diharuskan untuk memberikan perhatian secara komprehensif terhadap penggunaan materi, media, dan aktifitas pembelajaran di kelas. Guru diharapkan dapat menjadi guru yang baik dalam memfasilitasi proses pembelajaran.
\end{abstract}

Kata kunci: pengajaran berbicara, keterampilan berbicara, film 


\section{INTRODUCTION}

Nowadays the foreign language learners in school are rather heterogeneous not only as far as their proficiency level is concerned but also when it comes down to their interests and learning strategies. Marimba (1999:79), "Interest is the tendency of soul towards something consisting of interest in it, which is generally containing with pleasure feeling towards something". Interest refers to the maximum desire of someone to do or to get something (Syah, 1995:136).

Moreover, Sudirman (2004:76)

"Interest is a condition happening if someone looks the characteristic of a condition related to the desire or needs". Interest will appear if someone is interested in something important to fulfill the basic needs. Thus, this should be taken into account when planning teaching and lessons. One way of bringing variety and flexibility into the classroom is the use of film in EFL teaching.

As stated by The Department of Education and Cultural stated in English curriculum of Senior High School 2004 (2004), English is considered as a first foreign language and becomes a compulsory subject from elementary to university. In the context of education, the function of English language is as a tool to communicate in order to access the information, to make interpersonal relationship, to exchange information and also to enjoy the art of language in English culture.

Students hesitate to participate in discussion because they are not used to speak in class. Therefore, teachers could ask students to tell about the last film they saw and review it for the class, students begin to communicate with each other and eventually feel comfortable voicing their opinions on more weighty topics. As we know that, students really enjoy watching movies and TV for a variety reason. First, they get exposure to natural language in a non-threatening setting. Secondly, movies and video provide common ground to students of any international background. It will help them to improve their pronunciation and intonation and to assimilate English sentence structure. Teaching English through movies is undoubtedly one of the most effective and easiest tools we can utilize.

Film can bring variety and flexibility to the language classroom by extending the range of teaching techniques and resources, helping students to develop all four communicative skills. For example, a whole film or sequence can be used to practice listening and reading, and as a model for speaking and writing. Film can also act as a springboard for follow-up tasks such as discussions, debates on social issues, role plays, reconstructing a dialogue or summarising. It is also possible to bring further variety to the language learning classroom by screening different types of film: featurelength films, short sequences of films, short films, and adverts.

Given the benefits of using film in the language learning classroom, it is not surprising that many teachers are keen to use film with their students, and an increasing number of them are successfully integrating film into the language-learning syllabus. Until quite recently it was difficult to find pedagogically sound film material to help students improve their language through watching film, and teachers had to spend many hours creating their own materials. However, with the advance of the internet there is now a wealth of online resources for both language teachers and their students. With so many resources, it iss sometimes difficult for teachers to see the wood for 
the trees.

To perform the visual and simple teaching methodology, professional teachers who teach English can use video or movie as the tool to improve the student's ability in speaking and listening. It is sometimes for the students easily get bored with the classroom's environment while the teacher explains the materials without visualized. Movie will help them to love English. If they love English they will learn it and if they learn it they will speak to express their opinion about something. As affirmed by Bailey (2005) that speaking is an interactive process of constructing meaning involving a production and a process of information. It is often spontaneous, open-ended, and evolving (Bailey, 2005).

\section{METHOD}

The method of this present research examines the use of film as a teaching model applied in the classroom. To perform better technique, teachers use some characters of film as a media to teach speaking to students. There are three phase techniques conducted as follows:

\section{Pre-Teaching Activities}

It is the first stage before teaching process is conducted. This stage is called as pre-teaching activity.

2. Whilst-Teaching Activities

This phase aims at gaining basic competence which is done interactively, joyfully, challengingly, and motivionally. This stage is considered as the main activity in which the lesson begins to be introduced, delivered and practiced during the class. In this activity, is divided into three main stages, they are exploration, elaboration and confirmation.

3. Post-Teaching Activities

This stage delivers sharing session between teacher and students. in this case, the repetition of lesson is conducted to give a review and feedback for them to get a better learning process by examining such better activities than the former.

\section{RESULTS AND DISCUSSION}

The movie is the output that contains the animation and any sound you may have added. The Still Motion Creator can produce Flash SWF files and video (AVI) files with add on modules. There are no program restrictions on the maximum length of a Movie.

To implement movies criteria to Senior High School, three things are important, namely:

1. Educational

Typical movie should be educative for students to watch and has a correlation to the materials of English study.

2. Informative

After the students watch movie, they must get a new information about something not just only English but also any aspects that provided by the movie.

3. Entertaining

To attract the students' attention, the film should be entertained them to avoid the boredom with the class room's environment.

In order to achieve a success in teaching speaking using media film, English teacher should do some preparations. They are:

1. Materials

a. The teacher prepares well the material before coming to the classroom. The main thing that should be prepared is preparing the film itself.

b. The teacher selects the film and burns it on CD or in flashdisk.

c. The teacher uses film as a media in teaching speaking.

d. The teacher prepares some pictures. 
e. The teacher prepares projector, laptop or computer and speaker as a main media.

f. The teacher makes lesson plan which includes standard competence and basic competence.

2. Class Setting

a. The teacher chooses classroom.

b. The teacher makes the classroom become dark by turning off the lamp and closes the curtain.

c. Tables and chairs are moved to the back of the class.

\section{Teaching Model}

Teaching model using film as a media applied by using three phase techniques. They are pre teaching, whilst teaching and post teaching. In this case, the teacher uses some characters of film as a media to teach speaking to students.

1. Pre-Teaching Activities

The first stage is called preteaching activity. In this teaching activity, the teacher starts the meeting in the classroom. It ussually takes arround ten to fifteen minutes. The activities involved in this stage are:

a. The teacher greets the students.

b. The teacher checks the student's attendance.

c. The teacher checks the student's readiness to study. The classroom is clean, the students are on their seats, and the sitting arrangement is steady.

d. The teacher does the apperception. Apperception means the activity which emphasizes to recall what students have learned in the previous meeting.

2. Whilst-Teaching Activities

In this activity, the process is aimed to reach basic competence which is done interactively, joyfully, challengingly, and motivionally. Whilst-
Teaching Activities is the main activity in which the lesson begins to be introduced, delivered and practiced during the class. In this activity, is divided into three stages: exploration, elaboration and confirmation.

\section{a. Exploration}

In the exploration, the teacher and students do some activities to activate background knowledge and stimulate the students' imagination with the material given. The aim of this stage it should build up the students' background knowledge which has the relationship with the topic that will be learnt. Students are involved in getting information broadly about what is learning and teacher wants students to be cooperating and autonomous people.

The teacher builds the student knowledge by showing some pictures. After showing the picture, the teacher asks the students some questions example; What is your favorite film? Have you ever watched the ...... (name of film)............? Do you know the character in the film? What do you thing about ......... (star character of film)....? where do usually watch the film? If the students have given their answer, the teacher writes the students answer in the board.

b. Elaboration

Elaboration is an activity in which students are given more chance to achieve knowledge by doing some activities to make their understanding. Teacher facilitates students by giving them some tasks, discussions and so forth. The students are facilitated to learn cooperatively and collaboratively. However, there are some procedures that have to be followed by the students. First, the teacher divides the class into several small groups. 
Each of groups has three members. The member of each group are chosen support all of students to be active in discussion and they can help each other to be active. Second, each of member has different position in discussion but all of member should be active and work together in giving idea. Not only just leader of member who can give a conclusion for all of idea share but also all of the member can speak up. While the group discussion, the teacher must lead them and check their job. All the group have finished in the time given.

\section{c. Confirmation}

Teacher's job is to do confirmation to all of students. In the other words, the teacher gives a positive feedback and emphasizes what they have done. The teacher gives exercise to the student.

\section{Post-Teaching Activities}

In post-teaching activity, the teacher motivates student who did not participate yet. Teacher and students repeat again some expression of speaking that they have just learnt. In this phase, the teacher also asks students to watch other episode, and find new expression individually, but it will be homework for the students, because of the limited time in teaching and learning process. The teacher asks every student to tell the story more in the next meeting. It will make the students continue to learn about English speaking at home. The teacher concludes the lesson and closes the class by pray.

\section{CONCLUSION}

Based on the previous discussion, it can be concluded that in order to help the students to practice their speaking skill, the teacher should pay more attention to material, media and activities in the class. The teacher is expected to be a good teacher in facilitating the learning process. He or she should be able to create some activities that can help students to understand what they are learning. film with its features can be used as a material to teach. It helps the students to learn new expression items from the film. Therefore, film is one of alternative teaching materials that can help either teacher in teaching speaking or students in practicing their speaking skill.

In order to make students eager in studying English. The writer would like to give some suggestions that may be useful for English teachers. The writer wants to recommend English teacher to use appropriate methods in teaching speaking than the traditional one (the teacher only teaches the students by English textbook and later ask students to answer those questions, which relate with the topic that is being taught) because today's requirement is the teacher should be attractive and creative in learning process.

In addition, the students can encourage themselves to create new and creative ways of teaching by using various material and media, so that the students enjoy to learn English speaking without having afraid of grammar mistakes and expression. It is suggested that using film as one of materials can be used in teaching English speaking. It can be done out of classroom by using laptop, computer or television. Hopefully, the teacher would use film to increase the student's interest and motivation in practicing English speaking.

\section{REFERENCES}

Departemen Pendidikan dan
Kebudayaan. (2004). Kurikulum
2004 GBPP SMA. Jakarta.


Bailey, K. M., \& Nunan, D. (2005). Practical English Language Teaching Speaking. New York: McGraw-Hill.

Marimba, A. D. (1999). Islam Education

Philosophy Acknowledgment. Bandung: PT Al-Ma'arif.
Sudirman, A. M. (2004). Studying and Learning Motivation. Jakarta: PT. Raja Grafind Persada.

Syah, M. (1995). Education Psychology. Bandung: Remaja Rosda Karya 